into the blood, leads to disorder of cerebral function; that failure to function properly on the part of the liver, kidney, spleen or other organ, modifies the activity of the brain; and that, on the other hand, altered function in the brain may disturb the functions of these other organs. The medical profession is fully aware of the fact that man thinks not only with his brain, but in a certain sense with every organ in his body. In other words, we know that the perfection of activity of the brain is modified and determined by the proper and healthy activity of other organs of the body, although we are ready to admit that our knowledge along this line is by no means complete. We have studied in myxedema the effect of disordered function in the thyroid upon the central activity. We have learned that in chronic malaria, the central activities, the ideals and the philosophy not only of the individual but of nations, may be debased; that in uncinariasis and other forms of parasitism like results may follow. In short, medical observation and study have shown that healthy cerebral function is to be found only when the activity of the brain is properly influenced by normal function of all the correlated organs. We know equally well the influence of the brain on the other organs of the body. We are fully aware of the fact that impulses may be started in the brain through any of the five senses that may favorably or unfavorably influence the activities of correlated organs, and for centuries the medical profession has employed this physiological principle in the treatment of disease. Savory dishes, pleasingly garnished, through the sense of sight and smell tempt the appetite and stimulate the flow of the digestive juices. Cheerful surroundings aid digestion. Cheering words improve the circulation, and hope is often the best tonic that the physician can administer. As I have stated, the medical profession has understood and has utilized these physiological facts for centuries, and there is nothing in them to justify the founding of any new cult. That the brain of one individual may be modified in its activity by the sounds that fall from the lips of another is as much of a physical fact as that of the contraction of a muscle by the passing of an electric current through its nerve. There is nothing in this to justify a dualistic doctrine involving the existence of mind apart from and superior to matter. Indeed, every step in the process is in accord with the laws of physics and chemistry. The vocal organs of the speaker set in motion the sound waves that strike upon the ear of the hearer, the auditory nerves carry the impulse to the brain center, and the brain molecules respond. There is nothing in it that the most materialistic of philosophers might not endorse. Sensibility, or the capability of responding to stimuli, is, as Claude Bernard said, to a certain extent the startingpoint of life; it is a primary phenomenon and from it all others, physiological, intellectual and moral, develop. Bechterew holds that irritability or sensibility is due to a motile cohesion in the biomolecule, and that psychical activity is the result of a complex function of this molecule. Since nothing comes from nothing, the basis of psychical action must lie in the physicochemical elements of the organism.

VICTOR C. VAUGHAN

UNIVERSITY OF MiCHIGAN

\section{ETHNOLOGICAL EVIDENCE THAT THE \\ CALIFORNIA CAVE SKELETONS ARE NOT RECENT}

Since the discovery of the celebrated Calaveras skull, many human skulls and skeletons have been found in caves along the west slope of the middle Sierra. ${ }^{1}$ The presence of human

${ }^{1}$ See Sinclair, Univ. Calif. Pubs., Am. Arch. and Eth., Vol. 7, No. 2, 1908. 
remains in these caves has been interpreted to mean that the Indians now living in the region practise cave burial, or did practise it until recent times. This is an error. The Indians of this region, the Mewuk, burned their dead, and never under any circumstances put them in caves. These Indians believe the caves to be inhabited by a stone giant, whom they call Chehalumche, who sallies forth at night in search of food. He preys, by preference, on people, but when he can not get people, takes deer or other animals. He never eats his victims in the open but carries them into the caves and there devours them. Members of several subtribes of the Mewuk have told me this, and have looked with horror on the suggestion that they or their ancestors might ever have put their dead in caves. They say: "Would you put your mother, or your wife, or your child, or any one you love, in a cave to be eaten by a horrible giant?" The idea is so abhorrent to them that the theory of cave burial must be abandoned as preposterous. The Mewuk feel that the finding of human bones in these caves must convince us of the truth of their belief in the occupancy of the caves by Chehalumche, the bones being those of the victims he has carried there.

The mythology of the Mewuk does not admit of any migration but describes the creation of the people in the area they still inhabit. This, in connection with the fact that these Indians speak a language wholly different from any known in any other part of the world, proves that the Mewuk have occupied the lands they now occupy for a very long period-a period which in my judgment should be measured by thousands of years.

This argues a great antiquity for the cave remains, for they must be those of a people who inhabited the region before the Mewuk came-and this takes us back a very long way into the past.

\section{Hart Merriam}

\section{FRU SIGNE RINK}

WE regret to announce the death, April 19, in Kristiania, Norway, of Fru Signe Rink, widow of the late H. Rink, formerly Danish governor of Greenland and supervisor of the
Greenland commerce; and known all over the world for his valuable contributions to the ethnology of the natives of Greenland and the Eskimo people generally. Fru Rink survived her husband many years, and was the author of several little books and other writings on the tales, home life and traditions of a people with whom she had a partial connection by blood. Probably no one in Europe had a more intimate knowledge of their character, though it was with difficulty she could be persuaded to the publicity of authorship. Personally she was of a most kindly, hospitable and vivacious disposition, and her death will leave sorrow in many hearts. A daughter resident in Kristiania survives her.

$$
\text { W. H. DALL }
$$

\section{EXHIBIT OF THE BUREAU OF EDUCATION AT THE ALASKA-YUKON-PACIFIC EXPOSITION}

The plans of the National Bureau of Education for an exhibit at the Alaska-Yukon Exposition have been formed with special reference to the interests of teachers and officers of education.

In the section assigned to the bureau in the government building, a conference room has been fitted up where visiting educators will find ready welcome. Here they may consult publications pertaining to current movements in education, and a select reference library for teachers. The classified catalogue of this library will be furnished upon request. Arrangements for professional conferences in this room at stated hours may be made if desired.

The space surrounding the conference room is given up to exhibits pertaining to movements for the uplift and extension of rural education. These exhibits illustrate what is actually being done for the improvement of rural schools in the more progressive communities, and thus by concrete examples suggest the means of meeting needs which are felt in every part of the country. The separate exhibits have been prepared under the direction of a committee of the bureau appointed by the Commissioner of Education, assisted by expert collaborators in different sections of the country. 